\title{
HEBERDEN ORATION
}

\section{HEBERDEN'S NODES. A CLINICAL DESCRIPTION OF OSTEO-ARTHRITIS OF THE FINGER JOINTS*}

\author{
BY \\ ROBERT M. STECHER \\ From the Department of Medicine of the Western Reserve University School of Medicine \\ at City Hospital, Cleveland, Ohio
}

(RECEIVED FOR PUBLICATION SEPTEMBER 29, 1954)

It is indeed a great honour to be invited to deliver the Heberden Oration and to thus be linked with such medical scholars as have appeared in this role in the past. It is hoped that they will not feel uneasy at being forced thus to be associated so intimately with me! It is indeed a happy occasion to be invited to talk to the Heberden Society which includes among its membership so many close friends. It was my pleasure to be a dinner guest at a meeting of the Society in 1947, when Dr. Copeman was President.

Above all, it moves me deeply to have this opportunity to pay my respects to the man you have chosen as your patron, William Heberden, after whom your Society has been named. I, too, quite independently, chose him as my patron over 15 years ago when starting to study Heberden's nodes. My attempt to answer a simple question, which I thought might take several months, started me on a quest which is still continuing. My talk to-day is about what Heberden called digitorum nodi, which have come to be known throughout the world as Heberden's nodes. During his lifetime Heberden was a leading clinician, a successful practitioner, an author, and an essayist. He was the first to study and describe angina pectoris. His commentaries on disease, which were written in Latin, were translated into English and published posthumously. So far as I can find what he wrote amounted to 79 words in English about enlargement of the fingers (Heberden, 1803):

What are those little hard knobs, about the size of a small pea, which are frequently seen upon the fingers, particularly a little below the top, near the

* The Heberden Oration was given at The Postgraduate Medical School of London on September 24, 1954. joint? They have no connexion with the gout, being found in persons who never had it; they continue for life; and being hardly ever attended with pain, or disposed to become sores, are rather unsightly than inconvenient, though they must be some little hindrance to the free use of the fingers.

It is obvious that his words about digitorum nodi have set some kind of a record for effective brevity!

The really significant statement was that the nodes were certainly not due to gout. He did not say what they were, so I have more or less deliberately perverted the term to mean degenerative joint disease or osteo-arthritis of the finger joints.

Let me here acknowledge the assistance received in this work from my collaborators, each a specialist in his own field, without whose help this story would not have been possible. They include Dr. A. H. Hersh, Professor of Biology at Western Reserve University, whose advice, consultation, and statistical computation made the work on genetics possible, Dr. H. Hauser, for taking and interpreting the radiographs and collaborating on the question of radiological appearances, Dr. E. E. Beard, for collaborating on the study of the menopause, and Dr. L. J. Karnosh for help on the effect of nerve injury on Heberden's nodes. The help and friendship of these men have been precious for many years.

\section{Incidence}

My interest in this condition was aroused after seeing a man with well-developed enlargements of the fingers (Fig. 1, overleaf). He told me that he had four sisters with the same condition. The question arose whether or not this combination of disease was significant, or whether it might have affected five members of the same family by chance alone. The only way to settle this question was to discover 

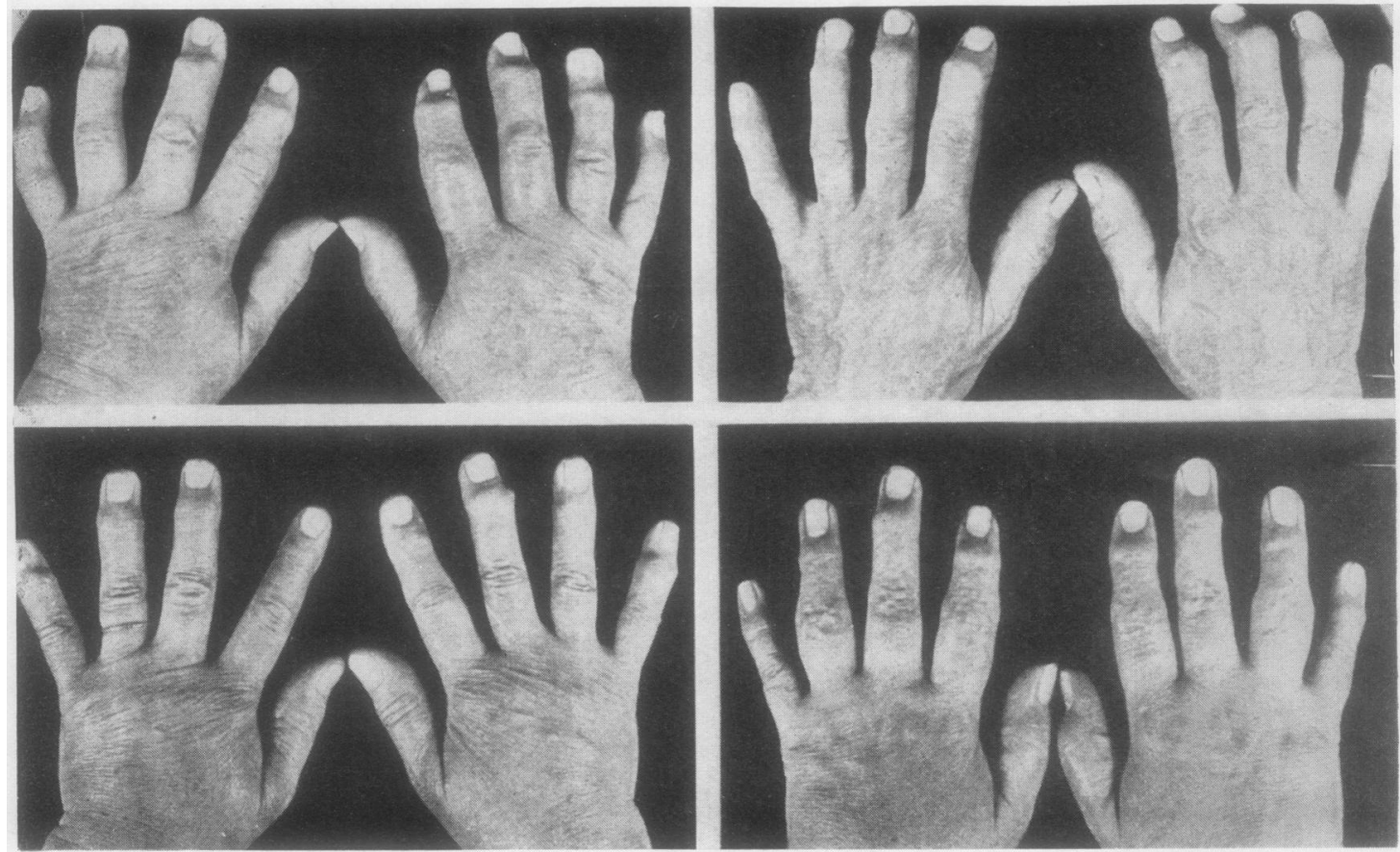

Fig. 1.-Hands of four living affected members of one family, showing well-marked Heberden's nodes.

the incidence of this disease in the population in general. Nearly 8,000 subjects were examined and the incidence determined for each sex and decade of age (Stecher, 1940).

This survey showed that enlargement of the terminal joints of the fingers arose in two different manners. Many men of all ages with one finger enlarged stated that this was the direct result of a single, painful injury. The commonest accident recorded was that of being hit on the end of the finger by a baseball. The finger became very painful, it swelled immediately, remained tender and sore for days to weeks, and became deformed, reaching a resting stage in several months. No further finger became involved, and it was concluded that this was a true traumatic arthritis to be designated traumatic Heberden's node. This deformity, once produced, lasted throughout the remainder of life, and was found in men of all ages, the incidence increasing with age. On the other hand, women related that one finger began to enlarge gradually in the late forties without known precipitating cause, other fingers became enlarged one after another until many or nearly all of the fingers were involved. The fingers were sensitive and tender during the period of development, but this phase passed after a few months. This condition was designated idiopathic Heberden's nodes.
Familial Involvement

When the incidence of Heberden's nodes had been determined for various sex and age groups it was easy to compute the probability of the disease occurring by chance alone in any family group (Stecher, 1941). In the family cited above, it was found to be one chance in ten million. In other large families, depending upon the numbers and age of the people involved, it was found to be one chance in five million and one chance in two hundred. The probability of seeing three families, constituted as has been described and occurring by chance alone, can be computed by multiplying ten million by five million by two hundred, so that it would have been necessary to examine every family on earth from the beginning of time to find the combination reported. It was apparent that some factor other than chance determined this phenomena, and heredity seemed the best explanation.

To test this hypothesis further family histories were obtained of the fingers of the mothers and sisters of 64 patients with Heberden's nodes. Most 0 of the sisters, both affected and non-affected, were $\mathbb{D}$ examined personally. When these women were $\stackrel{?}{+}$ sorted into age groups by decades and the incidence $T$ for each decade applied, idiopathic Heberden's

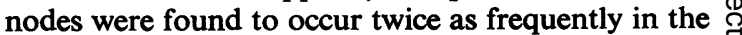
mothers and three times as frequently in the sisters 
of affected women as could be expected in the general population on the basis of chance alone. As a further check a control series was developed by examining the sisters of women at the City Hospital who had no joint disease. Heberden's nodes occurred about as frequently in these sisters as would be expected in the general population, and this further strengthened the conviction that idiopathic Heberden's nodes were determined by heredity.

\section{Mode of Inheritance}

An attempt was then made to determine the mode of inheritance of this condition (Stecher and Hersh, 1944). By this time pedigrees of 74 persons had been assembled and an analysis was made of these data. The affected propositi and their siblings included 127 men and 215 women. The difference in the number of men and women in the group is due to the fact that 72 of the 74 propositi were women. When these are subtracted from the total group there remains 125 men and 143 women, a fair approximation to the proportions of men and women in the general population of this age distribution.

Examination of the pedigrees showed at once that the incidence in women was high compared to that in men. For this reason each sex was considered separately in a genetic analysis. Considering first the women, it was found that 108 of the 215 women, or one half, were affected, the $1: 1$ ratio suggesting immediately that the character depends upon a single autosomal dominant gene. When this is the case one parent is invariably expected to be affected. Actually, mothers were recorded as affected in 25 of the 74 families. In two families the maternal grandmother was involved, but the mother, dying before the age of 35 , had been spared. Only one father was recorded as affected, but this family added nothing to the genetic analysis because the mother was also affected and only one daughter, the propositus, resulted from the match. In four families in which the mother was unaffected, there was reason to believe that the character was transmitted through the unaffected father. In two of these instances, the paternal grandmother and in two other instances a paternal aunt had Heberden's nodes. In eleven families, including the two mentioned above, the mothers died before the age of 50 , so might have been genetically affected without demonstrating the character. In four families the women were affected in three successive generations. Of the $\mathbf{7 4}$ families some antecedent involvement was discovered in 42 instances but was lacking in the 32 others.

Although Heberden's nodes may seem to be dominant in women the condition is certainly not so in men. Of the 127 males of this series only four were recorded as affected. Heberden's nodes may be recessive. Genetic examples are known of factors dominant in one sex and recessive in others. These include colour variation in cattle, the development of horns in sheep, and hereditary baldness in humans. Baldness is dominant in men and recessive in women. With a heterozygous constitution (Aa) men develop the trait and transmit baldness to one half of their offspring. Women with this constitution do not exhibit the condition but transmit it to one half of their children. Women become bald only when they are homozygous $(A A)$. With Heberden's nodes the simplest modification is to assume that the condition is recessive in men. With matings of a heterozygous person with normal $(A a \times a a)$, one half of the children will be heterozygous $(A a)$. The women of this constitution will develop Heberden's nodes while the men will not. The men who have Heberden's nodes are homozygous $(A A)$. According to this assumption an equal number of men and of women are of the heterozygous $(A a)$ constitution. Such men were assumed to have been the fathers in those families where no antecedent involvement was known. Furthermore, for a man to be affected, both parents must transmit the character to him, though only the mother is likely to show it.

\section{Gene Frequency Analysis}

The above hypothesis was tested by gene frequency analysis. For the subsequent discussion $D$ was used to represent the dominant gene for Heberden's nodes and $d$ the recessive normal allele. In the former study the highest incidence in white women over 70 years of age was found to be about 30 per cent. If this is accepted as complete penetrance we may assume that 70 per cent. of women are homozygous recessives and are $d d$ in constitution or completely normal so far as Heberden's nodes are concerned (Table I).

TABLE I

$$
\begin{gathered}
\text { GENE FREQUENCY CALCULATION OF } \\
\text { HEBERDEN'S NODES } \\
D^{2}+2 D R+R^{2}=1
\end{gathered}
$$

\begin{tabular}{|c|c|}
\hline Persons & Genes \\
\hline $\begin{array}{ll}D^{2} & =0.027 \\
2 D R & =0.272 \\
R^{2} & =0.700\end{array}$ & $\begin{array}{l}D=0.163 \\
R=0.837\end{array}$ \\
\hline $\begin{array}{ll}\text { Total } & 0.999\end{array}$ & $1 \cdot 000$ \\
\hline
\end{tabular}

The proportion of the 30 per cent. who are 
$D D$ and $D d$ in constitution may be readily calculated from the well-known formula for gene frequency analysis in a population in genetic equilibrium mating at random. According to the formula, homozygous dominants $D D$, heterozygous $D d$, and homozygous recessives $d d$, are present in the population in the relative numbers $Q^{2}, 2 P Q$, and $P^{2}$ respectively, where $P+Q=1$.

Since $P^{2}=0.70, P=0.837$, from which $Q$ is readily known from the relations $P+Q=1$. The values of $2 P Q$ and $Q^{2}$ are also easily calculated. The result shows that individuals with the constitutions $D D, D d$, and $d d$ are present in the population in the relative proportions of $0.027,0.272$, and 0.70 respectively. According to this hypothesis males of the constitution $D d$ are phenotypically normal. Only 2.7 per cent. of males have a genetic constitution which would cause the trait to develop.

\section{Types of Matings}

Since the proportion of the various constitutions for Heberden's nodes are known, the types of matings which can be expected to occur at random can be predicted (Table II). The top figure gives the proportion of each type of mating expected in the general population. The figure in brackets gives the actual number of each type of mating expected in this group of 74 families. Since each pedigree was discovered through an affected child and never from a parent, no mating of type $d d \times d d$ is included.

TABle II

TYPES OF MATING FOR HEBERDEN'S NODES

No. in brackets $=$ Actual No. Expected

\begin{tabular}{|c|c|c|c|}
\hline \multirow{2}{*}{$\begin{array}{c}\text { Constitution } \\
\text { of } \\
\text { Fathers }\end{array}$} & \multicolumn{3}{|c|}{ Constitution of Mothers } \\
\hline & $\begin{array}{c}D D \\
q^{2}=0.027\end{array}$ & $\begin{array}{c}D d \\
2 p q=0.272\end{array}$ & $\begin{array}{c}d d \\
p^{2}=0.70\end{array}$ \\
\hline $\begin{array}{c}D D \\
q^{2}=0.027\end{array}$ & $\begin{array}{l}0 \cdot 00073 \\
(0 \cdot 1)\end{array}$ & $\begin{array}{l}0 \cdot 0073 \\
(1 \cdot 1)\end{array}$ & $\begin{array}{l}0 \cdot 0189 \\
(2 \cdot 8)\end{array}$ \\
\hline $\begin{array}{c}D d \\
2 p q=0.272\end{array}$ & $\begin{array}{l}0.0073 \\
(1 \cdot 1)\end{array}$ & $\begin{array}{c}0 \cdot 074 \\
(10 \cdot 8)\end{array}$ & $\begin{array}{c}\begin{array}{c}0 \cdot 1904 \\
(28 \cdot 0)\end{array} \\
\end{array}$ \\
\hline $\begin{array}{c}d d \\
p^{2}=0.70\end{array}$ & $\begin{array}{c}0 \cdot 0189 \\
(2 \cdot 8)\end{array}$ & $\begin{array}{c}\begin{array}{c}0 \cdot 1904 \\
(28 \cdot 0)\end{array} \\
\text { (28) }\end{array}$ & $\begin{array}{c}0.490 \\
\text { (None) }\end{array}$ \\
\hline
\end{tabular}

Although is was not possible to recognize the different genotypes with certainty in all families, an attempted rough classification was justified. A total of 44 families with inheritance from the mother were expected. Of these 29 were identified with a fair degree of certainty; these include 25 families with the mother affected, two families with maternal grandmother affected, and two additional families with affected sons. If ten other families, omitted from the above classification because the mother died so young that her constitution could not be recognized, are considered as having heterozygous mothers, this group becomes 39 compared to 44 expected theoretically. Assuming random mating, twelve heterozygous fathers are expected in this group of $\mathbf{4 4}$ families leading to double inheritance, and a $3: 1$ ratio of expected affected. Of the $\bar{\sigma}$ 29 families identified, therefore, we expect an $\mathbb{D}$ appreciably greater frequency than the straight $1: 1 \stackrel{\circ}{\circ}$ ratio. According to the table of matings $28 \mathrm{c}$ families are expected with no parents showing the $\overrightarrow{0}$

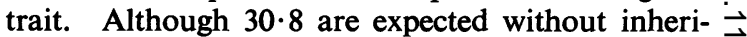
tance from the mother, 35 families are found. In $\omega$ these families it is concluded that inheritance is through the father and the rate $1: 1$ is expected.

\section{Correction for Small Family Size}

The above ratios are theoretical and cannot be 응 realized in human material such as is dealt with here. Corrections can be made for small family size and $z$ for lack of penetrance. The desirability of the first is obvious. Although one half of the children of $\stackrel{5}{工}$ affected families are expected to be affected, this $\vec{\bullet}$ ideal is upset by the vagaries of chance. Some of families will have one half of the children affected, some may have all the children affected, and some may have none affected; and every possible combination may be met with. Such variations as these array themselves according to the quadratic equation. If one starts only with affected individuals and studies their siblings, as we have done here, those families without affected children will not be included and the results will exceed the usual Mendelian ratios. It is therefore necessary to correct for small family size. The corrections are made according to the method of Hogben. Table III shows 29 families with maternal inheritance. Of 3 95 daughters, 57 are observed affected compared with $55 \cdot 446$ expected affected.

TABLE III

HEBERDEN'S NODES

SISTERS AFFECTED/EXPECTED AFFECTED

(Correction for small family size-Mother affected)

\begin{tabular}{c|c|c|c|c|c}
\hline \multirow{2}{*}{$\begin{array}{c}\text { Family } \\
\text { Size }\end{array}$} & $\begin{array}{c}\text { No. of } \\
\text { Families }\end{array}$ & \multicolumn{2}{|c|}{ Sisters } & \multicolumn{2}{|c}{ Ratio } \\
\cline { 3 - 6 } \cline { 4 - 5 } & Total & Affected & Factor & Expected \\
\hline 1 & 5 & 5 & 5 & $1 \cdot 0$ & $5 \cdot 0$ \\
3 & 8 & 16 & 10 & $1 \cdot 333$ & $10 \cdot 664$ \\
4 & 3 & 9 & 6 & $1 \cdot 714$ & $5 \cdot 142$ \\
5 & 5 & 20 & 8 & $2 \cdot 133$ & $10 \cdot 665$ \\
6 & 5 & 25 & 11 & $2 \cdot 581$ & $12 \cdot 905$ \\
8 & 2 & 12 & 10 & $3 \cdot 048$ & $6 \cdot 096$ \\
\hline Total & 1 & 8 & 7 & $4 \cdot 016$ & $4 \cdot 016$ \\
\hline Percentage & 29 & 95 & 57 & & $54 \cdot 488$ \\
\hline
\end{tabular}


Table IV shows 35 families without maternal inheritance. Of 96 daughters, 48 are found affected compared with $57 \cdot 64$ expected. A higher proportion of affected are found in the group with suspected double inheritance than in that with single inheritance.

TABLE IV

HEBERDEN'S NODES

SISTERS AFFECTED/EXPECTED AFFECTED

(Correction for small family size-No parent affected)

\begin{tabular}{|c|c|c|c|c|c|}
\hline \multirow{2}{*}{$\begin{array}{c}\text { Family } \\
\text { Size }\end{array}$} & \multirow{2}{*}{$\begin{array}{l}\text { No. of } \\
\text { Families }\end{array}$} & \multicolumn{2}{|c|}{ Sisters } & \multicolumn{2}{|c|}{ Ratio } \\
\hline & & Total & Affected & Factor & Expected \\
\hline $\begin{array}{l}1 \\
2 \\
3 \\
4 \\
5\end{array}$ & $\begin{array}{r}10 \\
3 \\
11 \\
8 \\
3\end{array}$ & $\begin{array}{r}10 \\
6 \\
33 \\
32 \\
15\end{array}$ & $\begin{array}{r}10 \\
3 \\
14 \\
15 \\
6\end{array}$ & $\begin{array}{l}1 \cdot 0 \\
1 \cdot 333 \\
1 \cdot 714 \\
2 \cdot 133 \\
2 \cdot 581\end{array}$ & $\begin{array}{c}10 \cdot 0 \\
4 \cdot 0 \\
18 \cdot 854 \\
17 \cdot 064 \\
7 \cdot 743\end{array}$ \\
\hline Total & 35 & 96 & 48 & & $57 \cdot 661$ \\
\hline \multicolumn{3}{|c|}{ Percentage } & 50 & & 60 \\
\hline
\end{tabular}

\section{Paternal Inheritance}

Attempts were made to correct for incomplete penetrance because of lack of age, but the details are not presented. They were very crude and gave results which were much too high. Instead, an effort was made to contact these subjects again and in the course of 12 years, two women formerly negative in the group with uninvolved mothers and four women in the group with mothers involved developed Heberden's nodes. This brought the percentage affected to 50 per cent. in the first group and 60 per cent. in the second group. It was assumed that in families without affected parents the trait was transmitted by a heterozygous father, and 50 per cent. affected was to be expected among the daughters. The affected mothers mating at random had a 30 per cent. chance of having heterozygous husbands (Table V).

TABle $\mathrm{V}$

FAMILIES WITH HEBERDEN'S NODES

\begin{tabular}{c|c|c|c}
\hline \multicolumn{2}{c|}{ Types of Matings } & Affected & Normal \\
\hline (1) Normal mother + Carrier father & $1: 1$ & 50 & 50 \\
(2) Affected mother + Normal father & $1 \vdots 1$ & 50 & 50 \\
(3) Affected mother + Carrier father & $3: 1$ & 75 & 25 \\
\hline
\end{tabular}

AFFECTED MOTHER WITH RANDOM MATINGS IN 100 FAMILIES (per cent.)

\begin{tabular}{c|c|c|c|c}
\hline Type & No. of Matings & Affected & Normal \\
\hline 2 & 70 & $1: 1$ & 35 & 35 \\
3 & 30 & $3: 1$ & $22 \cdot 5$ & $7 \cdot 5$ \\
\hline Total & 100 & & $57 \cdot 5$ & $42 \cdot 5$ \\
\hline
\end{tabular}

In 70 per cent. of the normal families, 50 per cent. of the daughters, and in 30 per cent. of the families with heterozygous fathers 75 per cent. of the daughters, are expected affected. In the combined group $57 \cdot 5$ per cent. are expected affected.

\section{Double Inheritance}

In twelve families with known double inheritance because of the appearance of affected sons, we expected a $3: 1$ ratio of affected daughters. These families had 33 sons and 29 daughters. Of the sons fourteen out of 33 were found to be affected, very close to a $1: 1$ ratio. Only $1: 3$ is expected here, but the result is biased because of the small number of sons and the fact that the families were chosen because of an affected son. Twenty of 29 women were found affected. This is $20: 9$ or $2 \cdot 2: 1$, somewhat lower than the theoretical expectancy but much higher than the usual $1: 1$. Two of the above sibships were used in a subsequent study of a large family of three generations in which expressivity was discussed at length. Two women who theoretically and genetically should have had Heberden's nodes are listed as normal. They do show small concretions of calcium in the tendonous attachments of the extensor tendons which may qualify them as genetically affected. If two normals of these nine are transferred to the twenty previously accepted positive cases, it would show 22 affected against seven normals, slightly over the $3: 1$ theoretical expectancy.

Therefore it is our concerted opinion that idiopathic Heberden's nodes depend upon a single autosomal gene sex influenced to be dominant in females and recessive in males. The gene frequency in the general population is $0 \cdot 163$, and three constitutions are recognized in the population:

$D D$, homozygous affected $0 \cdot 027$, the incidence in men,

Dd or heterozygous constitution $0 \cdot 272$, the sum of these constitutions $0.027+0.27=0.297$ or 0.30 give the incidence in women and dd $\mathbf{0 . 7 0}$ which is homozygous normal. Homozygous affected women have not been identified.

\section{Association with Other Forms of Arthritis}

A survey was undertaken to determine the frequency of osteo-arthritis of the various joints of the hand (Stecher, 1950). The results are shown in Fig. 2 (overleaf). It is obvious that both hands are about equally involved. In the order of decreasing frequency, it is seen that involvement affects the 


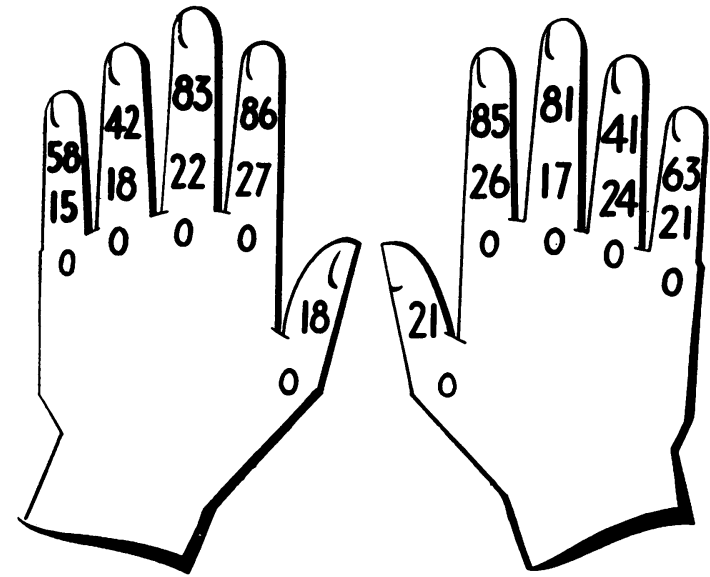

Fig. 2.-Distribution of arthritis in 100 pairs of hands.

terminal joints of the index finger, the middle finger, the little finger, and the ring-finger. The proximal joints of the four fingers are involved in about one-fourth of the cases and there is a substantial increase of involvement in the proximal joints of the right hand over the left hand. It is seen that the distal joint of the thumb is involved as frequently as other proximal joints. The metacarpophalangeal joints have never shown involvement in our observations. This experience has made it reasonable to diagnose osteo-arthritis of the proximal joints of the fingers, whereas before rheumatoid arthritis seemed the only proper diagnosis.

The association of Heberden's nodes with osteoarthritis of other joints of the body was then considered (Stecher, 1946a). Heberden's nodes in the past have been considered as "The commonest manifestation of degenerative joint diseases" and as "diagnostic of degenerative joint disease". Such general statements have not been confirmed in our studies. In a series of 94 women with Heberden's nodes, twelve (12.6 per cent.) were found to have other osteo-arthritis. In eleven patients this involved one knee, in one patient it involved one hip. It was never severe enough to incapacitate the patient, but it did cause inconvenience and discomfort in most instances. Deformity was not marked. Limitation of motion and crepitus was noted in all the affected knees. Several patients had a decided limp and required a cane or crutch. All took acetylsalicylic acid and many had resorted to physical therapy, diathermy, or massage. Apart from the twelve patients just mentioned, nineteen complained of arthritis or rheumatism. They had transient stiffness, occasional soreness, and question- able swelling, and resorted to acetylsalicylic acid for relief. These symptoms were troublesome but they were not objective signs of disease warranting a clinical diagnosis of degenerative joint disease. All knees were tested by palpation during motion for crepitus. Crepitus was noted in 35 (36 per cent.) of the cases. This condition was often unnoticed by the patient. It cannot be considered normal, but it does not of itself warrant a diagnosis of degenerative joint disease, and is not necessarily a forerunner of future joint disability. The significance of crepitus in these cases is not clear. Of 109 patients of the control series, three had definite degenerative joint disease of the knee, diagnosed because of pain, limitation of motion, and deformity, and comparable to that of the persons mentioned in the first group. No instance of other arthritis and rheumatism except ankylosis of one knee due to tuberculosis without objective signs were discovered in this series. Crepitus was noted in only 25 or 23 per cent. of the subjects.

The differences revealed between the two series are more apparent than real. The patients with Heberden's nodes were examined many times over a long period. There was thus frequent opportunity to complain of rheumatism or of arthritis or to discover crepitus. The members of the control series were seen but once and since they had not been thinking about arthritic complaints it seems certain that many details were overlooked. The fact remains that 94 patients with Heberden's nodes showed relatively little crippling generalized degenerative joint disease. I do not believe that Heberden's nodes are a part of a generalized osteoarthritic syndrome.

\section{Heberden's Nodes and the Menopause}

A definite association was established between the development of Heberden's nodes and the menopause (Stecher and others, 1949). This was found in a series of 99 women in whom the age at onset of Heberden's nodes was compared with age at the menopause. These events occurred within one year of each other in ten instances and within 3 years of each other in one half of the cases. In individual patients Heberden's nodes appeared at times ranging from 20 years before to 15 years after the menopause. The coefficient of correlation was found to be +0.46 , indicating odds of less than $1: 1,000,000$ that such a correlation would occur by chance alone. Even this high degree of correlation does not prove that the climacteric is a cause of Heberden's nodes. The average age at the menopause was 46.2 years in the fifty women in whom 
the earliest onset of Heberden's nodes was at 33 to 49 years. The average age at the menopause was 50.5 years $(4.3$ years later) in the 49 women in whom the onset of Heberden's nodes occurred later, from 50 to 65 years. It is most likely that these events have aetiological factors in common. Both must be considered as manifestations of the ageing process. Since Heberden's nodes occur only in people who are genotypically susceptible, the climacteric has to be considered as a contributory though important factor in their production.

\section{Importance of Nerve Supply}

Heberden's nodes apparently fail to develop in the absence of a normal and intact nerve supply to the fingers or hands. They have failed to develop in the presence of peripheral nerve damage, spinal cord disease, or palsies of cerebral origin. Stecher and Karnosh (1947) described a woman with a median nerve injury of the right hand who later developed Heberden's nodes in all fingers except those supplied by the injured nerve, the left second, third and fourth fingers. In a second case, a woman with weakness and partial lack of development of the right hand due to former anterior poliomyelitis had marked Heberden's nodes on the unimpaired left hand only (Fig. 3).

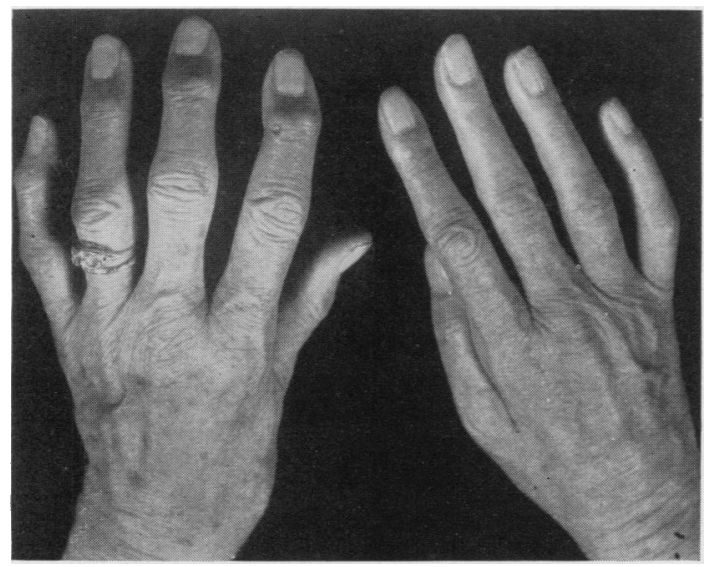

Fig. 3.-Hands of a woman with Heberden's nodes in the left hand only, the right having been affected by anterior poliomyelitis.

Similar cases have been seen and described by Hench (1947) and Beard (1947). Heberden's nodes also failed to develop in hands paralysed by cerebral accidents, although present on the normal side in cases described by Coste and Forestier (1935). Trophic disturbances after identifiable injury to the central nervous system lead to increased circulation to the limb, demineralization of the bones, and protection against the development of Heberden's nodes. A total of three such cases from our own experience and nine from the literature may be cited.

The literature about Heberden's nodes is not profuse but two studies recently reported (Peltola and Ahto, 1953; Roversi and Mars, 1954) are interesting. These workers found cervical arthritis in patients with Heberden's nodes and attributed the nodes to pressure or irritation of the nerves by exostoses emerging from the spinal canal. What the mechanism of such an influence may be is obscure. This hypothesis is at complete variance with our own observations and conclusions. Clinically, no trophic disturbance of skin or finger tissues nor alteration in normal circulatory control have been described in Heberden's nodes, but the few cases examined since these publications came to our attention have revealed exostoses, decreased width of intervertebral disks, and bone condensation in the cervical region.

\section{Other Clinical Features}

Blood Pressure.-To determine whether the condition was associated with high blood pressure (Stecher and Hauser, 1948), a comparison was made between 112 women with Heberden's nodes and 92 women of approximately the same age distribution, but otherwise selected at random. It was found that average blood pressure for each age group by decades was the same. After combining the series into one group no significant association between Heberden's nodes and hypertension could be demonstrated. In a series of 82 women with hypertension, Heberden's nodes were not found more frequently than could be expected from their incidence in the population in general. It was concluded that the relation of Heberden's nodes to hypertension does not differ from that of degenerative disease of other joints.

Obesity.-Although a strong positive association has been demonstrated between degenerative joint disease and obesity, no such association was found in this series; in this respect there is a wide difference between Heberden's nodes and other degenerative joint disease.

Roentgenological Appearance.-A detailed study was made of the clinical and roentgenological appearances of osteo-arthritis of the finger joint (Stecher and Hauser, 1948). In the original survey 
Heberden's nodes were defined as enlargements of the terminal joints sufficient to be seen and felt as a definite bony ridge across the palmar and the dorsal surface of the last joint. The shape and size of this enlargement varied considerably. At times "two small nodules" were identified, but more often the enlargement consisted of a solid bony ridge. As the disease advanced a flexion deformity causes the end phalanx to bend inwards, and the final degree of involvement shows a lateral deviation from the straight line.

It soon became apparent that osteo-arthritis of the fingers was not confined to the terminal joints alone. In many cases the proximal joints were involved. As experience accumulated it became possible to diagnose osteo-arthritis of the finger joints with only the proximal joints involved. This condition accompanied general good health, lack of involvement of other joints, and middle age in women patients.

Conventional radiographs of the fingers as shown in posterior-anterior views of the hand were disappointing, but the lateral view invariably showed bone changes, in the form of spurs arising first from the proximal, dorsal aspect of the distal phalanx, the palmar surface of the proximal aspect of the distal phalanx, and the distal aspect of both dorsal and palmar surfaces of the distal end of the middle phalanges. These spurs varied in size and shape, the joint spaces being often uneven, and the surfaces unequal, and roughened. Demineralization of bone was never seen, and usually the joint surfaces showed increased mineralization.

Some patients who had had well-marked Heberden's nodes for 20 years showed no involvement of the proximal joints. Other patients showed involvement, beginning perhaps in the proximal joint, until most of the joints of the hand become involved. Changes in the proximal joints, which were usually obvious both in the postero-anterior and lateral views, consisted of a broadening in both diameters of the proximal end of the middle phalanx sometimes with overlapping of the distal end of the proximal phalanx. True spur formation of the proximal end of the middle phalanx was rarely seen, but it did occur from the distal end of the proximal phalanx. The joint spaces were markedly decreased and the bone characterized by condensation rather than rarefaction.

Trauma.-Heberden's nodes may be caused by injury (Stecher and Hauser, 1954); they reach a high incidence in men in the third decade of life. If trauma has been the cause the patient invariably remembers the incident and describes it vividly; the enlargement occurs promptly and the condition remains stationary thereafter. The radiographic appearances are differentiated, in that the most marked enlargement is seen in the dorsal spur arising from the proximal end of the distal phalanx. This is usually large and broad and has its beginning some distance away from the proximal end of the joint. The tip of the spur is broad and rounded, and the joint space usually unaltered.

\section{Study of a Large Family}

An opportunity to test some of these theories was offered by a large family with a high incidence of Heberden's nodes (Stecher and others, 1953), which offered data on thirty individuals in three generations, including nine affected individuals (Fig. 4).

Three sisters were involved in the first generation. The first sister had an involved daughter and three

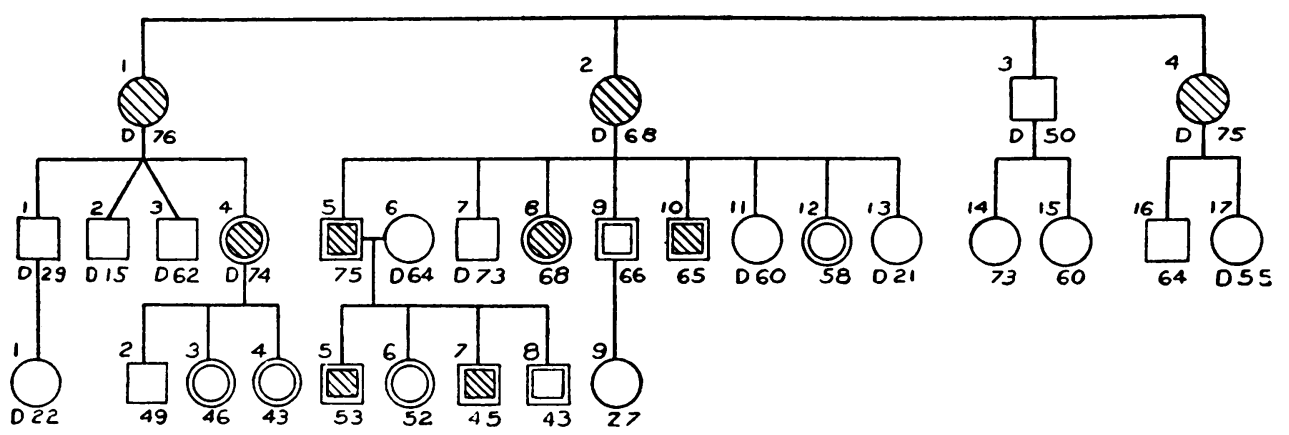

FIG. 4. Pedigree showing involvement in three generations.

Shaded individuals have idiopathic Heberden's nodes.

Symbol with double outline indicates that the individual was examined. II-9 and III-8 have traumatic nodes.

II-12 shows islands of bone, which probably represent poor expressivity of idiopathic Heberden's nodes. 
normal sons. The second sister mothered eight children, of which two brothers and one sister are involved. The first of this second sister's sons fathered four children; of three sons, two were involved, and the one daughter was rated negative. The third sister had a son and a daughter, both of whom are reported normal.

Two men at least (II-9 and III-8) had traumatic Heberden's nodes only, and one man with marked idiopathic Heberden's nodes showed changes in the right middle finger consistent with traumatic Heberden's nodes. In as much as this finger enlarged years before the other and he did suffer an injury it seems that a diagnosis of traumatic nodes is justifiable. The sibship of eight children included four men and four women; of the four men, two, or one half, show idiopathic Heberden's nodes, and of the four women, only one showed idiopathic Heberden's nodes, whereas we should expect three of the four to be affected. One sister died at age 21 and must be ignored, but one died at 60 and was rated negative; we must accept this at its face value because these people were alert to the condition. One woman (II-12) aged 58 showed absolutely no clinical suggestion of Heberden's nodes, but lateral $x$-ray pictures showed small islands of bony spurs arising from the dorsal aspect of the proximal end of the distal phalanges, and though she was rated as negative, these findings are possible minor manifestations of Heberden's nodes.

If our theory is correct, the mother, II-6, of the family of four in the third generation, must have been involved. She is listed as normal, but according to the theory she must have had the constitution for Heberden's nodes; she had either not developed them when she died age 64 , or they were so poorly expressed that they were not recognized.

The woman represented in III- 6 must eventually develop Heberden's nodes, but when last seen at the age of 52, she showed no suggestion of the condition (radiographs were not taken).

This large kindred supports the theory of a single genetic sex-influenced factor, usually, but not always, dominant in women and recessive in men. The exceptions can be accounted for by lack of penetrance or poor expressivity.

\section{Conclusions}

Idiopathic Heberden's nodes may occur without clinical evidence of other osteo-arthritis. Involvements of knees, hips, and spine do occur, but no more frequently than in any group of women of comparable age. It is inevitable that osteo-arthritis should involve other joints in some patients with Heberden's nodes, but this association is without aetiological foundation. My accumulated experience of osteo-arthritis of the finger joints, hips, and spine strongly suggests that three separate diseases have been confused by giving them the same name. This opinion will be supported if further study is made of osteo-arthritis in different joints, and obvious differences in age at onset, sex ratio, menopause, heredity, injury, and developmental anomalies are found. The fact that the histological picture of these diseases seems to be similar should not be allowed to mislead us.

This is one type of osteo-arthritis in which even the books suggest that therapy is ineffective. It is my policy to tell patients that they have a hereditary disease which comes at the time of the menopause. Since they have chosen their parents ill-advisedly in this respect and since their menopause cannot be prevented, there is little likelihood of preventing their disease. If the chemical and endocrinological changes which take place at the time of the menopause were understood, it might be possible to prevent or counteract them and delay the development of Heberden's nodes. Since the population is increasing in age and a higher proportion of elderly people survive, the incidence of this disease in the general population is likely to increase. During the period of development the affected fingers are sensitive and may be painful. This pain can be minimized by the use of aspirin. Some doctors recommend paraffin baths, but the patients to whom this has been suggested have stated that the pain is so slight and the treatment is so troublesome that they prefer to do without it. Many physicians are injecting hydrocortone into the terminal joints with happy results. I have not undertaken this personally and have no evidence that it is any more effective than the wearing of a copper bracelet on the wrist or carrying a horse chestnut in the pocket. For most patients the appearance of Heberden's nodes causes distress because of the cosmetic effect and because of fear that the nodes indicate the development of a crippling disease. Such is not the case, and the physician should reassure his patients on this point.

It may seem strange to spend so much time on such a little problem. It takes considerable courage to specialize in arthritis of the finger joints, but these studies were undertaken because it seemed that Heberden's nodes presented a clear-cut, simple disease, which lent itself to easy diagnosis, and offered the opportunity for clinical and statistical investigation. It was thought that information about this type of osteo-arthritis might be applicable to other forms, but such has not been the case. Our studies of Heberden's nodes will have been 
justified if they serve as a stepping stone to better understanding of the more serious forms of joint disease.

\section{REFERENCES}

Beard, E. E. (1947). Personal communication.

Coste, F., and Forestier, J. (1935). Bull. Soc. méd. Hôp. Paris, 51, 772.

Heberden, W. (1803). "Commentaries on the History and Cure of Diseases", 2nd ed., p. 148. Payne, London.

Hench, P. S. (1947). Personal communication.

- - (1954). Ibid., 62, 452.

Peltola, P., and Ahto, A. (1953). Ann. Med. intern. Fenn., 42, 64.

Roversi A. S., and Mars, G. (1954). Reumatismo, 6, 221.

Stecher, R. M. (1940). New Engl. J. Med., 222, 300.

(1941). Amer. J. med. Sci., 201, 801.

(1946a). Arch. phys. Med., 27, 409.

(1946b). J. Lab. clin. Med., 31, 687

(1950). Rev. esp. Reum., 3, 310

Beard, E. E., and Hersh, A. H. (1949). J. Lab. clin. Med., 34, 1193.

and Hauser, H. (1948). Amer. J. Roentgenol., 59, 326.

(1954) Ibid. 72, 452.

and Hersh, A. H. (1944). J. clin. Invest., 23, 699. and Hauser, H. (1953). Amer. J. hum. Genet., 5, 46.
. Amvest., 23, 699.

—, and Karnosh, L. J. (1947). Amer. J. med. Sci., 213, 181.

\section{Nodosités d'Heberden. Description clinique de} l'ostéoarthrite des articulations des doigts

\section{RÉSUMÉ}

Les nodosités d'Heberden peuvent exister sans que l'ostéoarthrite se manifeste ailleurs. L'atteinte concomitante des genoux, des hanches ou de la colonne vertébrale peut bien se voir, mais pas plus souvent que chez d'autres femmes d'un âge correspondant. Chez quelques malades ayant des nodosités d'Heberden l'ostéoarthrite est censée de frapper d'autres articulations mais cela n'implique pas un lien étiologique. Mon ample expérience d'ostéoarthrite digitale, coxo-fémorale et vertébrale indique nettement qu'on tend à confondre trois maladies différentes après leur avoir donné un seul nom. On trouvera des preuves à l'appui de cette opinion dans l'étude plus approfondie de l'ostéoarthrite de diverses articulations et en observant les différences nettes dans l'âge de début, rapport des sexes, ménopause, hérédité, traumatisme et anomalies évolutives. Le fait que les tableaux histologiques de ces maladies se ressemblent ne devrait pas nous induire en erreur.

Il s'agit ici d'un type d'ostéoarthrite dont le traitement est si futile que même les manuels l'admettent. Je dis toujours à mes clientes que c'est une maladie héréditaire apparaissant à l'époque de la ménopause et comme, de ce point de vue, leur choix de parents n'a pas été trop heureux et leur ménopause est inévitable, il est peu probable que l'on puisse empêcher la maladie. Si l'on comprenait les changements chimiques et endocriniens à l'époque de la ménopause, on pourrait peut-être les prevenir ou combattre et retarder ainsi l'apparition des nodosités d'Heberden. En raison de l'augmentation de l'âge moyen de la population générale due à la survie d'un nombre plus grand des personnes âgées, la fréquence de cette maladie tendra à augmenter. A la période évolutive les doigts atteints sont sensibles et souvent endoloris. On peut atténuer la douleur grâce à l'aspirine. Certains médecins recommandent des bains de paraffine, mais les malades à qui on les propose répondent que leur douleur est si faible et le traitement si $\frac{\overline{5}}{3}$ incommode qu'ils peuvent bien s'en passer. Beaucoup de $\square$ médecins injectent de l'hydrocortisone dans les articu- $\bar{\omega}$ lations terminales avec heureux résultats. Personnellement, je ne l'ai jamais fait et je n'ai pas de raisons de croire que ce soit plus efficace qu'un bracelet en cuivre au poignet ou un marron d'Inde dans la poche. Les nodosités d'Heberden inquiètent les malades parce $\frac{\bar{\sigma}}{\bar{T}}$ qu'elles enlaidissent et parce qu'elles représentent la $\frac{\bar{\sigma}}{\partial}$ menace d'une maladie mutilante. Il n'en est pas ainsi $\overparen{\Phi}$ et le médecin doit les rassurer.

Nudosidades de Heberden. Descripción clínica de osteoartritis de las articulaciones digitales

\section{Sumario}

Las nudosidades de Heberden pueden existir sin osteoartritis en otras partes del cuerpo. El compromiso de la rodillas, caderas o de la columna vertebral se puede? observar, pero no es más frecuente que en otras mujeres $\vec{A}$ de edad correspondiente. En algunos enfermos con $\rightarrow$ nudosidades de Heberden la osteoartritis atacará inevitablemente otras articulaciones, pero esto no basta o para establecer una relación etiológica. Mi experiencia acumulada de osteoartritis digital, coxo-femoral y $\vec{z}$ vertebral sugiere fuertemente una confusión de tres enfermedades diferentes que han recibido un solo nombre. Esta opinión recibirá apoyo del estudio ulterior de la $\supset$ osteoartritis de varias articulaciones con observar las $\vec{\theta}$ obvias diferencias respecto a la edad de comienzo, proporción en los sexos, menopausia, herencia, trauma y anomalias evolutivas. El hecho de que los cuadros $\square$ histológicos de estas enfermedades se parecen no debería inducirnos a error.

Se trata aquí de un tipo de osteoartritis que hasta los manuales reconocen la vanidad de tratarla. Suelo decir á mis pacientes que sufren de una enfermedad市 hereditaria que aparece durante la menopausia y como, en este respecto, no escogieron sus parientes muy $\overrightarrow{\bar{O}}$ juiciosamente y no pueden evitar la menopausia, tampoco 3 se puede impedir la enfermedad. Si se comprendiera los cambios químicos y endocrinológicos durante la menopausia, quizás se podría prevenir o combatirlos y retrasar así la aparición de las nudosidades de Heberden. Al aumentar le edad media de la población general con la $\underline{\underline{Q}}$ sobreviviencia de un número mayor de las personas de $\bar{\sigma}$ edad avanzada, se anticipa la más frecuente ocurrencia 3 de esta enfermedad. En el período evolutivo los dedosi comprometidos son sensibles y dolorosos. Se puede윽 atenuar este dolor con aspirina. Ciertos médicos aconsejan baños de parafina, pero los enfermos a quienes음 se propone este remedio contestan que su dolor es de poca intensidad y el tratamiento poco cómodo de modo queo prefieren se pasar sin él. Muchos médicos inyectan hidrocortisona con resultados afortunados. Personal- $N$ mente nunca lo he hecho y no tengo razones para creers que ésta sea más eficaz que una pulsera de cobre en laN muñeca o una castaña de Indias en el bolsillo. LasNN nudosidades de Heberden molestan por razones cos- $\omega$ méticas y por el temor de una enfermedad mutiladora No es así en realidad y el médico debe tranquilizar ako enfermo. 